\title{
A model of real estate and psychological factors in decision-making to buy real estate
}

This article explores the psychological characteristics of potential real estate buyers connected with their decision to buy. Through a review of research, it reveals that most studies of psychological factors in the decision to buy real estate have a partial and dispersed orientation, and examine individual factors independently. It appears that the research area is lacking clearly defined models of psychological factors in the decision to buy real estate that would integrally and relationally explain the role of psychological characteristics of real estate buyers and their expectations in relation to a decision to buy. The article identifies two sets of psychological factors, motivational and emotional, determines their interaction with potential buyers' expectations when deciding to purchase real estate and offers starting points for forming a model.

Keywords: decision to buy real estate, psychological factors, expectations, motivation, emotions 


\section{Introduction}

The attractiveness and value of real estate are marked by market principles based on the most probable way of acting and behaving in the real estate market. These are of key importance when deciding to buy real estate. Jack P. Friedman and J. Bruce Linderman (2005) divide market principles into two main categories, which are based on principles related to the real estate itself and principles based on users' perceptions. The first principles are characterised by factors that we further divide into financial, physical, socio-economic and living environment factors (Grum \& Temeljotov Salaj, 2010), and the second principles relate to buyers' characteristics, among which psychological characteristics are the most important. Dan Andrews et al. (2011) and Jerome Dasso and Alfred A. Ring (1985) similarly divide factors that influence the demand for residential real estate.

As stated by Bijaya K. Shrestha (2010), a fixed expense such as food or clothing is a necessity of life, and without them life in a society is not possible. Homes are material resources and psychosocial status symbols that influence how people see themselves and are seen by others (Dunn, 2000). Poor housing conditions can lead to pessimism, passivity, chronic stress and general discontent (Cohen et al., 2000). Due to an economic crisis, which is part of the economic cycle and is a phenomenon when economic activities increase or decrease (Samuelson, 1995), it is increasingly necessary to coordinate the interests of potential buyers' expectations for buying decisions. However, as Simon Kušar (2012) points out, problems in the real estate market are not to be exclusively attributed to the global financial and economic crisis. In the case of the housing bubble, Robert Shiller (2006) notes that the strong increase in real estate prices was especially caused by psychological expectations and financial instruments that allow speculation with real estate. On the other hand, Richard Sendi (2010) and Sasha Tsenkova (2014) state that major differences can be observed in prices associated with the quality of housing.

Expectations can be understood as buyers' wishes or needs, or as their perception of what the supplier should offer (Lewis \& Spyrakopoulos, 2001). If a purchase takes place and this purchase satisfies the buyer's needs, then this purchase has fulfilled the buyer's expectations, and individuals' buying decisions result in their satisfaction, which becomes part of their experience (Lipičnik \& Možina, 1993). Purchasing takes place when the features of a product are equal to the expectation, or when the features of a product exceed a buyer's expectations and the buyer is satisfied (Oliver \& De Sarbo, 1988). Philip Kotler (1996) believes that people tend to decide to buy products that show their role and position in society. Although people belong to the same sub-cultural group, social class or profession, they may vary by lifestyle. The author also points out that a lifestyle is a pattern of living that is manifested through human activities, interests and opinions, and expresses the entire individual's personality, which is also influenced by the environment. According to him, individuals' shopping behaviour is undoubtedly also greatly influenced by their personality. The role of expectations when measuring the level of satisfaction related to real estate is also emphasised by Joseph J. Cronin and Steven A. Taylor (1992). As John O'Shaughnessy (1995) states, through purchases buyers look for products with features that best meet their needs, and behind this there is a human value system that influences an individual's preferences towards certain products.

Although many psychological factors are involved when deciding to buy real estate, researchers have not paid much attention to this area. Most studies (Holbrook \& Hirschman, 1982; Solomon, 2012) have been made based on studying consumers' behaviour in general; that is, how consumers behave when buying products or services, what influences the purchase, how they choose, and so on. In psychology, consumer behaviour is understood as shopping-related behaviour, which is influenced by the choice, availability and attractiveness of products or services aiming to satisfy one's needs (Kuester, 2012). According to Michael R. Solomon (2012), studies of consumer behaviour generally focus on the following aspects:

1. Decision-making in the buying process; namely, at the cognitive, motivational and emotional levels. This aspect concerns decision-making mechanisms such as mental processes, learning, memory, attention and so on, and emotional mechanisms, which means that the purchase decision involves emotional dimensions of an individual's personality (the emotional attitude towards a product or service, emotional associations that arise at the thought of a product or service, etc.). The motivation that comes second after the buying decision is one of the most important aspects in the psychology of consumer behaviour;

2. Demographic and behavioural characteristics of consumers in order to understand their shopping behaviour;

3. Influence of external factors, such as family, friends, reference groups, and immediate and broader social environment in order to understand consumer behaviour;

4. Knowledge and awareness of a consumer regarding the product or service; and

5. Market forces that influence the decision to buy.

The research problem in this article is to identify the psychological characteristics of potential real estate buyers that relate to their buying decision. The objectives are:

1. To identify the fundamental psychological factors of decision-making to buy real estate; 
2. To identify the overarching categories of psychological factors involved in decision-making to buy real estate;

3. To create a hypothetical model of psychological factors in decision-making to buy real estate.

This paper surveys the psychological characteristics of potential real estate buyers connected with their decision to buy. The main hypothesis is that in the decision to buy real estate two sets of factors are present: property factors that relate to real estate and psychological factors that relate to those that decide to buy real estate.

\section{Theoretical baselines}

Most studies of consumer behaviour focus on various aspects of the human psyche, such as personality and motivation (Schrocer, 1991), emotions (Holbrook \& Hirschman, 1982) and values (Kahle \& Kennedy, 1989). Here we briefly explain the connection of consumer behaviour with personality, motivation and emotions.

\subsection{Personality}

Personality is the "overall pattern of our mental, behavioural and physical characteristics by which each of us differs from others" (Musek, 2010: 10). Personality is a relatively permanent psychological quality that develops gradually, until entering adulthood, and then remains constant throughout the life of the individual. Janek Musek (2010) points out that personality is the most important psychological concept because it covers all human characteristics, in which personality traits have the greatest effect on individual behaviour. It is thus not surprising that a separate chapter in the psychology of consumer behaviour is dedicated to the influence of personality. This was especially typical for the 1960s, when researchers particularly examined whether it was possible to use knowledge of consumers' personalities to predict their behaviour (Evans, 1959; Solomon, 2012). More specifically, they sought to determine whether it is possible to use sophisticated persuasion skills to present products to buyers in order to influence individual personality traits so that individuals will buy those products. The answer lies in the definition of personality, which emphasises that personality traits, once developed, do not change easily (Albanese, 1990). Researchers even stated that other psychological factors are more important because they are more susceptible to environmental influence and more easily modified. These are primarily motivational and emotional factors (Schiffman \& Kanuk, 2010). Therefore, today most researchers focus on studying consumer behaviour in connection to psychological dimensions that are increasingly influenced by external factors, such as significant others, vendors, demographic environment and so on; namely, motivational and emotional factors.

\subsection{Motivation}

Motivation is a mental process that stimulates and directs an individual's behaviour towards a particular goal (Kobal Grum \& Musek, 2009). This means that motivation influences the direction, persistence and intensity of goal-oriented behaviour. Herbert L. Petri and John M. Govern (2004) emphasise that motivation is a psychological process that refers to behaviour and behaviour-associated feelings, thoughts, attitudes, perceptions, beliefs and other psychological aspects. Psychologists are mainly interested in the causes and purposes of human behaviour. In this context, motivation plays an extremely important role in consumer behaviour because it stimulates and directs consumers to identify and buy products or services. Researchers still follow Maslow's hierarchy of needs (Maslow, 1970), which classifies motives from the most basic ones, such as physiological motives or motives of absence, to psychological motives or motives of growth, among which the highest in the hierarchy is the motive for self-actualisation (van Raaij \& Wandwossen, 1978; Yalch \& Brunel, 1996). They look for different products or services for individual motives that will realise these motives. Thus, among some products or services, there are food products, medicines, recreational services (these satisfy physiological products), offers for life insurance, offers for pension plans, various security services (these meet security needs) and so on, up to offers for various courses, extracurricular activities, and cultural and artistic offers to satisfy the motive for self-actualisation (Dye et al., 2005). Where does the need or the motive to have one's own home rank? According to Maslow, this ranks among affiliation motives and reputation motives.

\subsection{Emotions}

Emotions and feelings are mental processes and states that reflect human values towards the outside world or to oneself (Kobal Grum \& Seničar, 2012). People get to know other persons, events and situations and emotionally evaluate them, determining their value for themselves. Feelings are therefore evaluations and occur with objects that are important for an individual. In terms of functionality, feelings have an adjustment function (they enable a person to efficiently adjust to the environment), they act as motives (directing one to objects and situations that trigger positive feelings) and they also play an important role in communication and regulation of social relations (for other people, they serve as information for how to regulate their behaviour; Musek, 2005). In the 1980s, researchers (e.g., Hirschman \& Holbrook, 1982; Gardner, 1985) began to focus more on how feelings are connected to con- 
sumer behaviour and what the role of feelings is in the buying process. Since then, the issue of feelings has been a constant in consumer psychology and research on consumer behaviour (Curren \& Goodstein, 1991; Murray \& Bellman, 2011).

\subsection{Neuropsychological correlates of motivation and emotions}

The role of motivation and emotions in consumer behaviour is also examined by neuropsychology today. Neuropsychological research uses functional magnetic resonance imaging to measure the activation and functioning of various brain centres; this shows that the behaviour of an individual as a consumer is also reflected in the functioning of specific brain areas (Murray, 2007; Shiv, 2007). Recent studies (e.g., Glimcher, 2011; Esch et al., 2012; Santos et al., 2012; Shiv \& Yoon, 2012) emphasise that when assessing brands the more active brain parts are those responsible for emotions, and less active ones are those responsible for receiving and processing information. In other words, when assessing which product to buy, people's brains process and transmit more messages related to emotional elements of the product, whereas the information about the characteristics of the product are not dominant. These findings suggest that if sellers wish to sell their products or services at good prices, it is more important to establish emotional relations towards the product among consumers than to provide accurate descriptions and details about the product.

\section{Methodology}

\subsection{Meta-analysis in the broader sense, or systematic review}

Meta-analysis is a complex statistical analysis used to examine and combine the results of a large number of studies that explore a related problem (Walker et al., 2008). According to Andrej Kastrin (2008), it consists of the following steps: research assumptions, definition of inclusion and exclusion criteria, search and selection of studies, quality assessment of studies, selection of data and results, standardisation and calculation of effect size, assessment of heterogeneity and sensitivity analysis, calculation of the total rate of the effect size and visualisation of results. Meta-analysis in a broader sense, sometimes also called systematic review (e.g., Torgerson, 2003; Higgins \& Green, 2011), provides detailed summaries of the best review studies related to the research question posed. Systematic review shares some steps with meta-analysis, although it is frequently oriented less towards quantity and more towards quality (Walker et al., 2008).

This article uses the basic form of systematic review by following these steps:
1. Research assumption:

- In the decision to buy real estate, two sets of factors are present: factors that relate to real estate (i.e., real estate factors) and factors that relate to the persons that decide to buy real estate (i.e., psychological factors);

2. Definition of inclusion criteria:

- Original or review article (dissertations not included)

- Clear methods and statistical data supporting the main findings

- Number of participants precisely defined

- Keywords in the title, summary, table of contents, aids, or main text;

3. Search and selection of studies:

- We started with research in the period between 2000 and 2014; the search was conducted in the EBSCO, PsychInfo, ProQuest, JSTOR and Emerald databases.

\subsection{Factor analysis}

An additional method we used is factor analysis of the questionnaire to measure expectations towards real estate (Grum, 2010; Grum et al., 2010), which was conducted on a sample of 1,006 adult participants. There were $495 \mathrm{men}$ and 511 women with the average age of 21.15 years (range 18 to 55 years). Most of them had completed secondary education (57.3\%) and 38\% had a tertiary education. Random sampling was conducted, in which participants completed the questionnaires mainly via the Internet or as paper-and-pencil forms during time spent at the faculty (i.e., students).

Factor analysis yielded four factors that are decisive when buying real estate. These are: financial, physical, living environment and socio-economic factors (Grum 2010; Grum et al., 2010). The questionnaires measuring expectations of potential homebuyers cover thirty-four variables. The factors extracted through the factor analysis partially overlap with the factors extracted in the questionnaire. The first factor is important in questions referring to finances (purchase funds, loans and time of purchase), and the second factor is important in questions referring to the expectations about physical factors of real estate (location, size of flat, age of building and age of neighbourhoods). The third factor is distinctive in questions referring to expectations regarding the living environment (proximity to public transport, good transport connections, proximity to schools and preschools, shops, medical facilities and proximity to employment opportunities) and the fourth in questions referring to expectations regarding socio-economic factors related to the real estate (maintenance costs, neighbourly relations, safety in the neighbourhood, social security, sense of a better position in the society, independence and selfsatisfaction). The Kaiser-Meyer-Olkin measure of sampling adequacy is 0.861 . Bartlett's test (BT $=2,654.756$, which is 


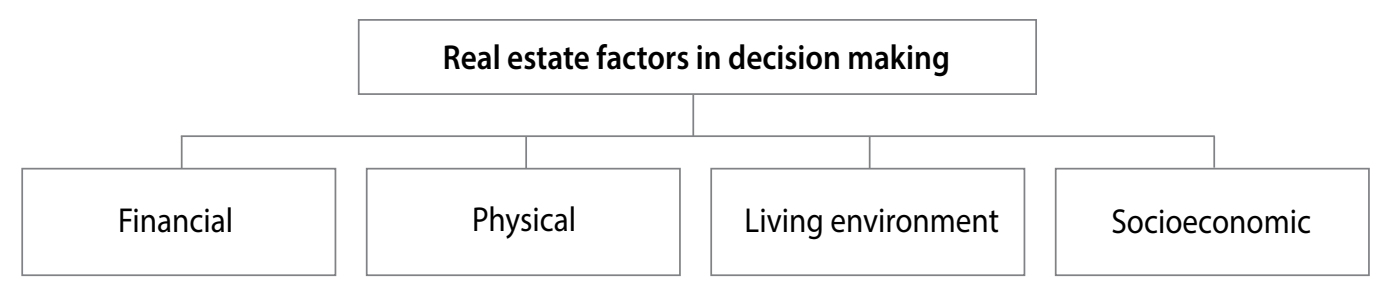

Figure 1: Analysis of real estate factors in the decision to buy real estate (adapted from Grum et al., 2010).

statistically significant) also shows that extracted factors can be interpreted (Fulgosi, 1984). Figure 1 schematically shows the distribution of real estate factors in the decision to buy real estate regarding the factor analysis.

\section{Results and interpretation}

\subsection{Results and interpretation of the results of the meta-analysis in a broader sense and factor analyses}

Table 1 shows the results of the meta-analysis in a broader sense, in which we included all articles relating to keywords. These are: potential real estate buyers, real estate buyers, potential home buyers, psychological characteristics, buying process and so on.

When the keyword buying process was entered, the EBSCO and psycINFO databases found ninety-two articles; however, most of them refer to compulsive shopping or buying processes referring to food products, and not to buying process referring to real estate. In combination with home buyers, no results were found. By using the Smart Text Searching program (in EBSCO), we discovered an article that examines the influence of family members on buying home products (Singh \& Goyal, 2010). The dependent variables were the prevailing opinion of the husband, the prevailing opinion of the wife, equivalent influence of both spouses and equivalent influence of all family members on the decision to buy home products. The independent variable was the location of the residence: urban or rural. The study covered 407 households in India, 204 urban ones and 203 rural ones. They noted that most processes connected to buying home products in rural areas are influenced by the male spouse's decision, whereas in the urban areas the decision is made equivalently by either both spouses or all members of the family. We would also like to point out a study (Hur \& Morrow-Jones, 2008) in which the authors asses owners' satisfaction with a flat or house regarding neighbourly relations. The independent variables were neighbourly relations and the dependent variable was the level of satisfaction with a flat or a house with respect to these relations.
There were 2,060 adult participants from the United States. The authors established that the level of owner satisfaction is most negatively associated with neighbours' social problems.

By entering the keyword housing, 239 articles were found, but only a few dealt with our problem. We highlight an experimental study (Tower-Richardi et al., 2014) in which the authors were interested in the correlation between deciding to buy real estate and the influence of purchase on social status. The dependent variable was social status and the independent one was purchase. The experiment included sixty adult participants and showed a positive correlation between the purchase of real estate and a sense of achieving a higher position in society for the new owner after buying the real estate. A study by Wojtek Tomaszewski and Francisco Perales (2014) also measures the sense of satisfaction and subjective wellbeing of the owners of real estate by different demographic groups. The combination of the keywords housing and motivation yielded nine articles, but they mostly deal with the problem of homelessness and mental disorders and none with the problem addressed here.

We also used the JSTOR database, for which the keyword home buyers yielded 2,359 articles; however, the review did not show any relevant articles for our research. Therefore, we entered a combination of the phrases motivation and emotion, but this also did not result in any psychologically based articles. With the same combination of phrases, the ProQuest database yielded three articles, but none of them met the criteria for further review. It is therefore evident that numerous research projects focus on various areas, but only a few of them correspond to our subject of research. It is our impression that research on psychological factors in the decision to buy real estate mainly deal with this problem in a partial and dispersed manner, and explore psychological effects on individuals' decision-making more individually and separately from each other. Thus, in this research area there are no clearly defined models of psychological factors for the decision to buy real estate that integrally and relationally explain the role of the psychological characteristics of real estate buyers and their expectations concerning the decision to buy. Therefore we used only those psychological factors in the decision to buy real estate that are 
also in this article's reference list (Holbrook \& Hirschman, 1982; Schrocer, 1991; Schiffman \& Kanuk, 2010; Solomon, 2012). These are factors that can more easily be influenced by external changes and are therefore more likely to be changed if influenced by certain mechanisms and factors. This is why this article uses a hypothetical model in which we assume two psychological factors that contribute significantly to individuals' decision to buy. These are the two fundamental drivers of human behaviour: motivational and emotional factors (Kobal Grum \& Musek, 2009).

Motivational factors that influence individuals' behaviour may be internal or external. As with any shopping behaviour, internal motivational factors are primarily related to basic motives, which appear as the level of satisfaction with basic needs expressed by the buyer. In line with one of the bestknown and proven psychological theories of motivation, selfdetermination theory (Deci \& Ryan, 2000), which emphasises that satisfied basic needs are the most important indicator of an individual's satisfaction, we assume that persons with more highly expressed internal motivational factors more often decide to buy real estate. We limit external motivational factors to those pointing at motives where, by buying real estate, individuals acquire self-validation in relation to others, by making a purchase to acquire a better status than others. Some authors call these motives of competitiveness (Franken, 2007).

Psychological studies show two dominant dichotomous factors of emotions, which are defined as positive and negative emotionality (Watson \& Tellegen, 1985). Positive emotionality is a state in which an individual is in a good mood, very enthusiastic, active and ready for action, whereas negative emotionality is a condition in which an individual is inclined to depression and anxiety, concerned and nervous. Positive and negative emotionality are of utmost importance in defining subjective emotional wellbeing; that is, overall emotional satisfaction with oneself and with one's life (Diener et al., 1999 Kahneman et al., 1999).

Among psychological factors, it is also necessary to mention the most important motivator of human behaviour, which is reflected as one of the most basic emotions: self-esteem. Self-esteem is individuals' positive or negative views of themselves (Rosenberg 1989). Positive position or high self-esteem means that individuals accept and appreciate themselves, are satisfied, feel themselves worthy of respect and so on. Following the model of internal emotional factors, where self-esteem stands out, among external emotional factors we can identify conditional self-esteem (Paradise \& Kernis, 2002). Overall self-esteem (i.e., internal emotional factors) is about the overall value attitude towards oneself, and in conditional self-esteem when estimating the one's value individuals depend on how
Table 1: Hits for keywords for meta-analysis for 2000-2014 in the EBSCO, Psychlnfo, JSTOR and ProQuest databases

\begin{tabular}{ll}
\hline Keywords & Published sources \\
\hline potential real estate buyers & 0 \\
\hline real estate buyers & 0 \\
\hline potential home buyers & 2 \\
\hline home buyers & 21 \\
\hline $\begin{array}{l}\text { potential home buyers \& psychological } \\
\text { characteristics }\end{array}$ & 0 \\
\hline $\begin{array}{l}\text { potential home buyers \& motivational cha- } \\
\text { racteristics }\end{array}$ & 0 \\
\hline potential home buyers \& motivation & 0 \\
\hline $\begin{array}{l}\text { potential home buyers \& emotional charac- } \\
\text { teristics }\end{array}$ & 0 \\
\hline potential home buyers \& emotion & 0 \\
\hline potential home buyers \& self-esteem & 0 \\
\hline home buyers \& psychological characteristics & 0 \\
\hline home buyers \& motivational characteristics & 0 \\
\hline home buyers \& motivation & 0 \\
\hline home buyers \& emotional characteristics & 0 \\
\hline home buyers \& emotion & 4 \\
\hline home buyers \& self-esteem & 0 \\
\hline buying process & 92 \\
\hline buying process \& home buyers & 0 \\
\hline home buying process & 0 \\
\hline housing & 2,359 \\
\hline housing \& motivation & 9 \\
\hline
\end{tabular}

they feel to be evaluated by others. Therefore, when deciding to buy real estate, individuals with high conditioned self-esteem decide whether to buy real estate or not depending on how they think they are evaluated by others with regard to the real estate they will to buy.

\subsection{Developing a model of real estate and psychological factors related to the potential decision to buy real estate}

Based on the factor analysis of the questionnaire for measuring expectations towards real estate, which extracted four factors that potential buyers use to form their expectations with regard to real estate, we considered the decisive factors as the basis for the hypothetical model. On one hand, there are financial and physical elements, elements of the living environment and socio-economic factors (Grum, 2010; Grum et al., 2010). We sought to determine how these factors are connected to psychological factors (i.e., motivational or basic and status motives) and emotional factors (i.e., level of emotionality and selfesteem). The model is shown in Figure 2. The model sums up the main research hypothesis of the article on the functioning 


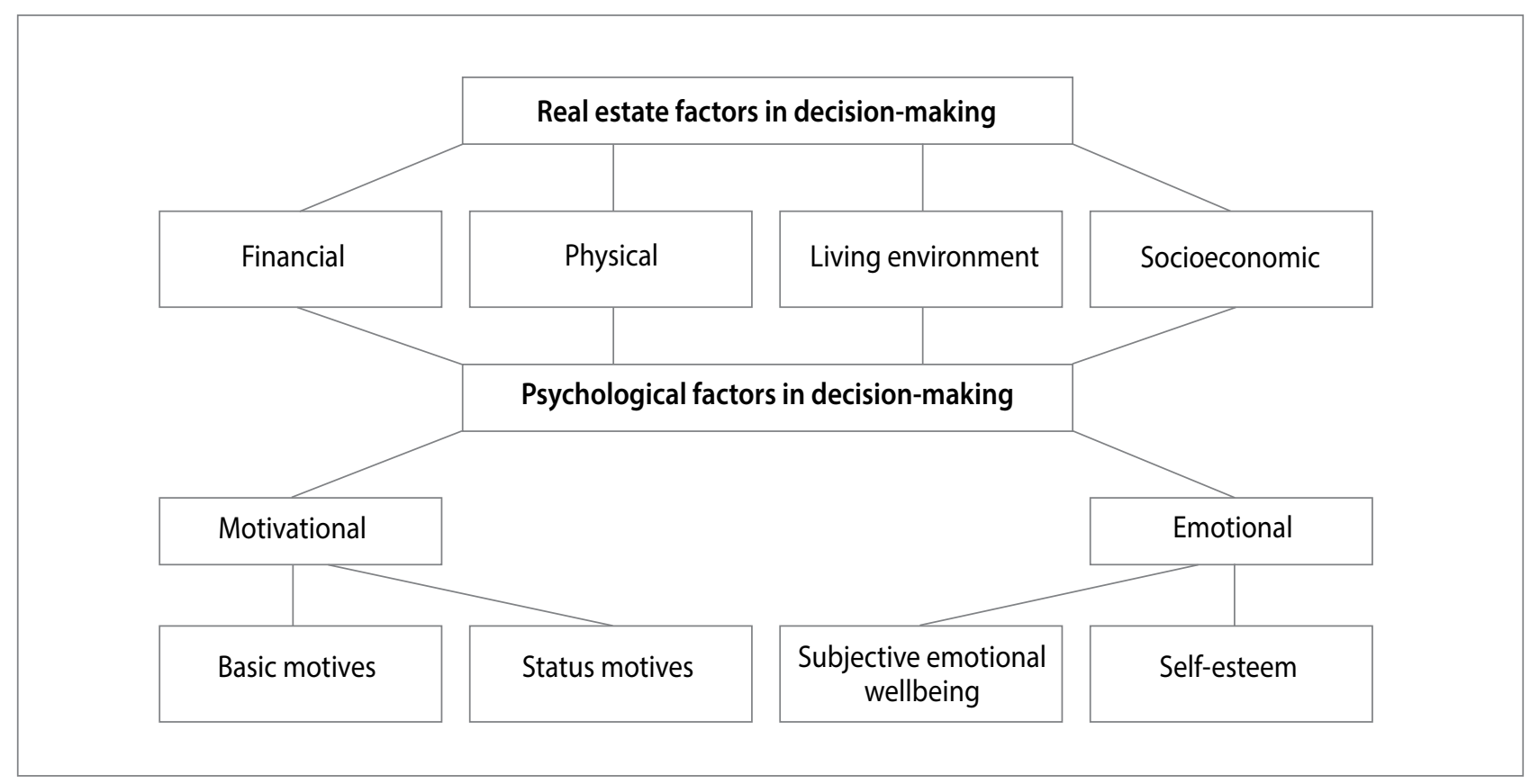

Figure 2: Hypothetical model of real estate and psychological factors in decision-making to buy real estate.

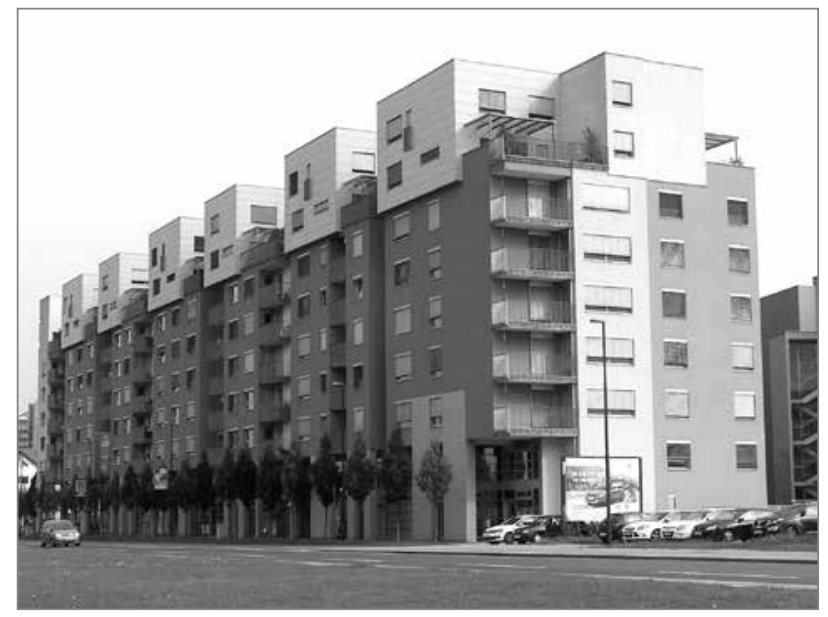

Figure 3: People with a higher level of satisfied needs are more satisfied with their real estate or have clearer and more positive expectations with regard to their purchase (foto: Boštjan Kerbler).

of the two groups of factors in the decision to buy real estate, the real estate itself and the psychological factors.

The model assumes that internal motivational factors encourage individuals' efforts to buy real estate. This means that people with a higher level of satisfied needs are more satisfied with their real estate or have clearer and more positive expectations with regard to their purchase. On the other hand, external motive to buy real estate lie in the desire to gain recognition or better social status. The model assumes that people with higher expression of this motive decide to buy real estate in order to improve their social status and prestige.
In relation to the emotional factors associated with the decisions to buy real estate, we believe that people with higher positive emotions have more positive expectations regarding the purchase of real estate than people with dominant negative affect. Between internal and external emotional factors is self-esteem, which on the one hand reflects the fundamental self-assessment of an individual based on one's internal tendencies and, on the other hand, self-assessment with regard to belief about how one is assessed by others or one's own value with regard to external factors. In other words, persons with a higher level of positive and stable self-esteem (i.e., internal self-esteem) have more positive and clear expectations with regard to purchasing real estate, whereas persons with distinctly conditioned self-esteem make their decisions to buy real estate depending more on what they think other people think of it or whether buying real estate would make a better impression on others and thus increase respect for themselves. It is also to be expected that persons with higher conditioned self-esteem also have a higher expressed external motive to buy real estate, which is a status motive in our model. The significance of positive and negative affect and self-esteem for an individual's property was also highlighted in a study recently conducted by Rosellini Ferraro et al. (2011), which notes that basic emotions (positive and negative affect) and self-esteem are significantly associated with what and how much an individual possesses. Interestingly, this research also connects specific areas of self-esteem (in our case, conditioned self-esteem) and external motivation (in our case, the status motive).

Based on the meta-analytical study and on our own research findings (Grum et al., 2010) it is possible to draw conclusions 


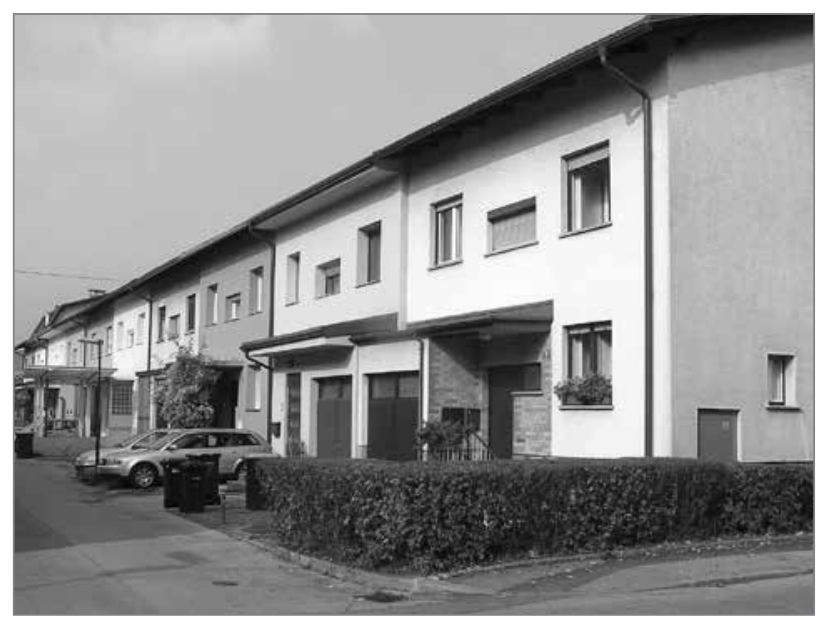

Figure 4: Persons with a higher level of positive and stable self-esteem (i.e., internal self-esteem) have more positive and clear expectations with regard to purchasing real estate (foto: Boštjan Kerbler).

about the setting of the hypothetical model of psychological factors in the decision to buy real estate, which integrally and relationally clarifies the role of psychological characteristics of real estate buyers in their expectations regarding the decision to buy. In our model, these are basic and status motives, subjective emotional wellbeing and self-esteem.

\section{Conclusion}

This study raises starting points that make it possible to study the importance of the interaction between real estate and psychological factors when making a decision to buy real estate at both the theoretical and empirical levels. It is one of the first attempts to explain the role of the psychological characteristics of real estate buyers and their expectations regarding the decision to buy without relying on a partial or incoherent interpretation of these factors. The study seeks to integrally and relationally explain the role of the psychological characteristics of real estate buyers and their expectations regarding their decision to buy, which is shown in the model in Figure 2. We summarised our starting hypothesis, which makes it possible to set up a hypothetical model of psychological factors in the decision to buy real estate. In our model, these are basic and status motives, subjective emotional wellbeing and self-esteem. The article identifies two psychological factors (motivational and emotional factors), determines their interaction with potential buyers' expectations when deciding to buy real estate and, based on this, develops a platform for designing the hypothetical model.

In the future it would be reasonable to empirically verify the model so that a set of psychological instruments covers the psychological factors in the model and connects them with real estate factors. Using confirmatory factor analysis, this would confirm or improve the current hypothetical model of psychological and real estate factors in the decision to buy real estate. Linked to real estate and its most economical use (as well as for planning development), it is important to know potential buyers' expectations regarding real estate itself, the psychological factors specific to the buyers and their mutual correlation. In the future, also from the point of view of sustainable land use, the model should be further developed and empirically linked with these real estate factors (financial, physical, environmental and socio-economic). Of course, as stated by Sendi (2013), housing needs are not determined only for the here and now, but are also planned for the future.

Limitations of the study are particularly seen in the fact that the model is hypothetically based on the results of foreign studies. Therefore empirical verification would definitely be needed. Another drawback is methodological. This article used only the initial part of the meta-analysis, which refers to the systematic review. In the future it would be useful to conduct a meta-analysis as a whole to obtain a more accurate overview.

Bojan Grum

European Faculty of Law, Nova Gorica, Slovenia

E-mail: bgrum@siol.net

Darja Kobal Grum

University of Ljubljana, Faculty of Arts, Department of Psychology,

Ljubljana, Slovenia

E-mail: darja.kobal@ff.uni-lj.si

\section{References}

Albanese, P. J. (1990) Personality, consumer behavior, and marketing research: A new theoretical and empirical approach. In: Hirschman, E. C. (ed.) Research in consumer behaviour, pp. 1-49. Greenwich, CT, JAI Press.

Andrews, D., Caldera Sanchez, A. \& Johansson, A. (2011) Housing markets and structural policies in OECD countries. Paris, OECD Publishing. DOI: $10.1787 / 5 \mathrm{kgk} 8 \mathrm{t} 2 \mathrm{k} 9 \mathrm{vf3}-\mathrm{en}$

Cohen, D., Spear, S., Scribner R., Kissinger, P., Mason, K. \& Wildgen, J. (2000) Broken windows and the risk of gonorrhoea. American Journal of Public Health, 90(2), pp. 230-236.

DOI: 10.2105/AJPH.90.2.230

Cronin. J. J. \& Taylor. S. A. (1992) Measuring service quality: A re-examination and extension. Journal of Marketing, 6(7), pp. 55-68.

Curren, M. T. \& Goodstein, R. C. (1991) Affect and consumer behavior: Examining the role of emotions on consumers' actions and perceptions. In: Holman, R. H. \& Solomon, M. R. (eds.) NA - Advances in consumer research, 18, pp. 624-626. Provo, UT, Association for Consumer Research.

Dasso, J. \& Ring, A. A. (1985) Real estate principles and practices. Englewood Cliffs, NJ, Prentice Hall.

Deci, E. L. \& Ryan, R. M. (2000) The "what" and "why" of goal pursuits: Human needs and the self-determination of behavior. Psychological Inquiry, 11(4), pp. 227-268. DOI: 10.1207/S15327965PLI1104_01

Diener, E., Suh, E. M., Lucas, R. E. \& Smith, H. E. (1999) Subjective 
well-being: Three decades of progress. Psychological Bulletin, 125(2), pp. 276-302. DOI: 10.1037/0033-2909.125.2.276

Dunn, J. R. (2000) Housing and inequalities in health: A study of socioeconomic dimensions of housing and self reported health from a survey of Vancouver resident, Journal of Epidemiology Community Health, 56(9), pp. 761-682.

Dye, K., Mills, A. J. \& Weatherbee, T. (2005) Maslow: Man interrupted: Reading management theory in context. Management Decision, 43(10), pp.1375-1395. DOI: 10.1108/00251740510634921

Esch, F., Möll, T., Schmitt, B., Elger, C. E., Neuhaus, C. \& Weber, B. (2012) Brands on the brain: Do consumers use declarative information or experienced emotions to evaluate brands? Journal of Consumer Psychology, 22(1), pp. 75-85. DOI: 10.1016/j.jcps.2010.08.004

Evans, F. B. (1959) Psychological and objective factors in the prediction of brand choice. Journal of Business, 32(10), pp. 340-369. DOI: $10.1086 / 294291$

Ferraro, R., Edson Escalas, J. \& Bettman, J. R. (2011) Our possessions, our selves: Domains of self-worth and the possession-self link. Journal of Consumer Psychology, 21(2), pp. 169-177.

DOI: 10.1016/j.jcps.2010.08.007

Franken; R. E. (2007) Human motivation. Belmont, Thomson/Wadsworth.

Friedman, J. P. \& Linderman, J. B. (2005) How to prepare for the California real estate exam: Salesperson, broker, appraiser. New York, Barron's Educational Series.

Fulgosi, A. (1984) Faktorska analiza. Zagreb, University of Zagreb, Faculty of Art.

Gardner, M. P. (1985) Mood states and consumer research: A critical review. Journal of Consumer Research, 12(12), pp. 281-300. DOI: $10.1086 / 208516$

Glimcher, P. W. (2011) Foundations of neuroeconomic analysis. New York, Oxford University Press.

Grum, B. (2010) Primerjava pričakovanj potencialnih kupcev nepremičnin glede pridobitve nepremičninskih pravic v različnih kulturnih okoljih: primer Slovenije in Japonske. Ph. D. Thesis. Nova Gorica, European Faculty of Law.

Grum, B. Kobal Grum, D. \& Temeljotov Salaj, A. (2010) Expectations of potential real estate buyers with reference to the acquisition of real estate rights in different cultural environments - construction of questionnaire. In: Antončič, B. (eds.) Conference proceedings, p. 12. Koper, Edukator.

Grum, B. \& Temeljotov Salaj, A. (2010) Pričakovanja potencialnih pridobiteljev nepremičninskih pravic $v$ Republiki Sloveniji glede na njihov spol, starost, izobrazbo in zaposlenost. Geodetski vestnik, 54(3), pp. 501-516.

Higgins, J. P. T. \& Green, S. (2011) Cochrane handbook of systematic reviews of interventions. Version 5.1.0 (updated March 2011). The Cochrane Collaboration. Available at: www.cochrane-handbook.org (accessed 1 Jul. 2014).

Hirschman, E. C. \& Holbrook, M. B. (1982) Hedonic consumption: Emerging concepts, methods and propositions. Journal of Marketing, 46(3), pp. 92-101. DOI: 10.2307/1251707

Holbrook, M. \& Hirschman, E. (1982) The experiential aspects of consumption consumer fantasies, feelings, and fun. Journal of Consumer Research. 9(2), pp. 132-140. DOI: 10.1086/208906

Hur, M. \& Morrow-Jones, H. (2008) Factors that influence residents' satisfaction with neighborhoods. Environment and Behavior, 40(5), pp. 619-635. DOI: 10.1177/0013916507307483
Kahle, L. R. \& Kennedy, P. (1989) Using the list of values (LOV) to understand consumers. Journal of Consumer Marketing, 6(3), pp. 5-12. DOI: 10.1108/EUM0000000002549

Kahneman, D., Diener, E. \& Schwarz, N. (eds.) (1999) Well-being: The foundations of hedonic psychology. New York, Russell Sage Foundation.

Kastrin, A. (2008) Metaanaliza in njen pomen za psihološko metodologijo. Psihološka obzorja, 17(3), pp. 25-42.

Kobal Grum, D. \& Musek, J. (2009) Perspektive motivacije. Ljubljana University of Ljubljana, Faculty of Art.

Kobal Grum, D. \& Seničar, M. (2012) Uvod v psihologijo prehrane. Ljubljana, University of Ljubljana, Biotechnical Faculty, Department of Animal Science.

Kotler, P. (1996) Marketing Managemnat - trženjsko upravljanje: analiza načrtovanje, izvajane in nadzor. Ljubljana, Slovenska knjiga.

Kuester, S. (2012) MKT 301: Strategic marketing \& marketing in specific industry contexts. Mannheim, University of Mannheim.

Kušar, S. (2012) Selected spatial effects of the global financial and economic crisis in Ljubljana, Slovenia. Urbani izziv, 23(2), pp. 112-120. DOI: 10.5379/urbani-izziv-en-2012-23-02-004

Lewis, B. R. \& Spyrakopoulos, S. (2001) Service failures and recovery in retail banking: The customers' perspective, International Journal of Bank Marketing, 19(1), pp. 37-47. DOI: 10.1108/0265232011036648

Lipičnik, B. \& Možina, S. (1993) Psihologija v podjetjih. Ljubljana, DZS.

Maslow, A. H. (1970) Motivation and personality. New York, Harper and Row.

Murray, E. A. (2007) The amygdala, reward and emotion. Trends in Cog nitive Sciences, 11(11), pp. 489-497. DOI: 10.1016/j.tics.2007.08.013

Murray, K. B. \& Bellman, S. (2011) Productive play time: How consumers optimize hedonic experiences, Journal of the Academy of Marketing Science, 39(3), pp. 376-391. DOI: 10.1007/s11747-010-0205-6

Musek, J. (2005) Predmet, metode in področja psihologije. Ljubljana, University of Ljubljana, Faculty of Art, Department of Psychology.

Musek, J. (2010) Psihologija življenja. Vnanje Gorice, Inštitut za psihologijo osebnosti.

Oliver, R. L. \& De Sarbo, W. S. (1988) Response determinants in satisfaction judgments. Journal of Customer Research, 14(4), pp. 495-507.

O'Shaughnessy, J. (1995) Competitive marketing: A strategic approach. Routledge, London.

Paradise, A. W. \& Kernis, M. H. (2002) Self-esteem and psychological wellbeing: Implications of fragile self-esteem. Journal of Social and Clinical Psychology, 21(4), pp. 345-361. DOI: 10.1521/jscp.21.4.345.22598

Petri, H. L. \& Govern, J. M. (2004) Motivation: Theory, research, and applications. Belmont, CA, Thomson/Wadsworth.

Rosenberg, M. (1989) Society and the adolescent self-image, Middletown, $\mathrm{CT}$, Wesleyan University Press.

Samuelson, P. A. (1995) Ecomomics. New Baskervill, Yourk Grafic Service.

Santos, J. P., Moutinho, L., Seixas, D. \& Brandao, S. (2012) Neural correlates of the emotional and symbolic content of brands: A neuroimaging study. Journal of Costumer Behaviour, 11(1), pp. 69-93.

Schiffman, B. \& Kanuk, L. L. (2010) Consumer behaviour. Sydney, Prentice Hall Australia.

Schrocer, R. (1991) Maslow's hierarchy of needs as a framework for identifying emotional triggers. Marketing Review, 46(5), pp. 26-28. 
Sendi, R. (2010) Housing bubble burst or credit crunch effect? Slovenia's housing market. Urbani izziv, 21(2), pp. 96-105.

DOI: 10.5379/urbani-izziv-en-2010-21-02-003

Sendi, R. (2013) The low housing standard in Slovenia: Low purchasing power as an eternal excuse. Urbani izziv, 24(1), pp. 107-124.

DOI: 10.5379/urbani-izziv-en-2013-24-01-002

Singh, J. \& Goyal, B. B. (2010) Influence of family members on household buying: A comparative study of rural and urban households. Interdisciplinary Journal of Contemporary Research in Business, 1(9), pp. 152-176.

Shiller, R. (2006) Irrational exuberance revisited. In: Sullivan, R. (ed.) Global perspectives on investment management: Learning from the leader, pp. 303-321. Charlottesville, VA, CFA Institute.

Shiv, B. (2007) Emotions, decisions, and the brain. Journal of Consumer Psychology, 17(3), pp. 174-178. DOI: 10.1016/S1057-7408(07)70025-6

Shiv, B. \& Yoon, C. (2012) Integrating neurophysiological and psychological approaches: Towards an advancement of brand insights. Journal of Consumer Psychology, 22(1), pp. 3-6. DOI: 10.1016/j.jcps.2012.01.003

Shrestha, B. K. (2010) Housing provision in the Kathmandu Valley: Public agency and private sector initiation. Urbani izziv, 21(2), pp. 85-95. DOI: 10.5379/urbani-izziv-en-2010-21-02-002

Solomon, M. R. (2007) Consumer behavior: Buying, having, and being (10th Edition). Upper Saddle River, NJ, Prentice Hall.

Tomaszewski, W. \& Perales, F. (2014) Who settles for less? Subjective dispositions, objective circumstances, and housing satisfaction. Social Indicators Research, 118(1), pp. 181-203. DOI: 10.1007/s11205-013-0420-x

Torgerson, C. (2003): Systematic Reviews. New York, Continuum International Publishing Group.

Tower-Richardi, S. M., Brunyé, T. T., Gagnon, S. A., Mahoney, C. R. \& Taylor, H. A. (2014) Living the high life: Social status influences real estate decision making. Journal of Applied Social Psychology, 44(9), pp. 611-621.

Tsenkova, S. (2014) The housing policy nexus and people's responses to housing challenges in post-communist cities. Urbani izziv, 25(2), pp. 90-106. DOI: 10.5379/urbani-izziv-en-2014-25-02-002

van Raaij, W. F. \& Wandwossen, K. (1978) Motivation-need theories and consumer behavior. Advances in Consumer Research, 5(1), pp. 590-595.

Walker, E., Hernandez, A. V. \& Kattan, M. W. (2008) Meta-analysis: Its strengths and limitations. Cleveland Clinic Journal of Medicine, 75(6), pp. 431-439. DOI: 10.1037/0033-2909.98.2.219

Watson, D. \& Tellegen, A. (1985) Toward a consensual structure of mood. Psychological Bulletin, 98(2), pp. 219-235.

Yalch, R., \& Brunel, F. (1996): Need hierarchies in consumer judgments of product designs: Is it time to reconsider Maslow's theory? In: Corfman, K. P. \& Lynch Jr, J. G. (eds.): NA - Advances in Consumer Research 23, pp. 405-419. Provo, University of Tennessee. 